To be Presented at The Tapicat Meeting on Advances in Reactor Physics, CharTeston, \$C, March 8-II, I992.

VaTidation of the REBUS-3/RCT MethodoTogies:

ANL/CF-T 3424

for EBR-II Core-FoTTow AnaTysis

DE9I $0.15 I 38$

\author{
R. I. Mcknight
}

Reactor AnaTysis Division
Arganne Nationat Latoratory
9700 South Cass. Avenue
Arganna, IL 60439
(TOQ) $972-6088$

\title{
DISCLAIMER
}

\begin{abstract}
This report was prepared as an account of work sponsored by an agency. of the United States Government. Neither the United Skates: Government nor any. agency thereof, nor any of theiremployess, makes any warranty. express ar implied, or assumes any legal liatility, or responsibility for the accuracy, conpleteness, or usefuliness of any information, apparatur, product, or process disclased, ar represents that its use would nat infringe privately owned rights: Reference herein ta any. specific conmercial product, process, ar service by trade name, trademark, manufacrurer, ar atherwise doex not necessarily. constitute or imply. its endorsement, recommendation, or favoring by the United States Gavernment ar any agency thereof: The views. and opinians of authors expressed herein do not aecessarily state or reffect those of the United States Government or any ageacy thereof.
\end{abstract}

* Wark supported by the U.S. Department of Energy, NucTear Energy Programs under Cantract W-3I-IOQ-ENG-3E. 
Valïdation of the REBUS-I/RCT Methodotogies for EBR-LI Care-Fallow Analysis

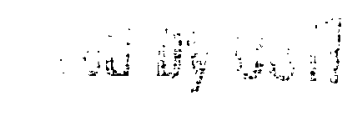

\author{
R. D. McKnïght \\ Reactor Analysis Division \\ Argonne National Laboratory
}

One of the many tasks to be completed at EBR-I/FCF (FueI Cycle Facility) regarding fuel cycte closure for the Integral East Reactor (IFR) is to develop and install the systems to be used: for fissite material accountancy and control [1]. The IFR fuel cycle and pyrometallurgicaI process scheme determine: the degree of actinide buildup in the reload fuet assemblies.. Inventories: of curium, americium and neptunium in the fuel will affect the radiation and thermal environmentaI conditions at the fuel fabrication stations, the chemistry of reprocessing, and the neutronic performance of the core. Thus, it is important that validated calculational tools be put in place for accurately determining isotopic mass anơ neutronic inputs to FCF for both operational and material control and accountancy purposes. The primary goal of this work is to validate the REBUS-3/RCT codes [2,3I as tools which can adequateIy compute the burmup andi isotopic distribution in binary-and temary-fueled Mark-III, Mark-IV, and Mark-V subassembties.

The validation procedure has involved obtaining the avaitable loading information for an EBR-II configuration which sufficiently preceded the rans of EBR-II into which were loaded: driver/test subassemblies that were ulimately analyzed for discharge compositions. Detailed REBUS-I modeling of the core loading and core power level history for that EBR-II rum is used: to calculate the bumup fistory. This process is: then extended throughi a series of all subsequenit EBR-II muns, where input to the REBUS-I lumup calculations: utilizes the known heavy metal Ioadings for freshIY-Ioaded subassemblies andi the calculated (REBUS-3) number densities for the remainder of the subassemblies. This procedure should approximate the energy and spatial distribution of the neutron flux for the fresfily-Loaded subassemblies. Therefore, after a series of EBR-II mus have been analyzed, the effect of the initial conditions (i.e., the coarse initial reactor Ioading data) should diminish. Deptetion anaIysis for a series of EBR-HI runs is then: repeated for specific experimental test subassemblies using the RCT code to obtain local values (e.g., values: for all axial segment of a single element within a subassembly) of the bumup and isotopic compositions. Validation of these analytical methods and procedures is then determined via comparison of calculatef etement discharge compositions witf experimentally measured bumup indicators (such as ${ }^{139} \mathrm{La}$ and ${ }^{148} \mathrm{NdEmeasurements}$ and $U$ and $\mathrm{Pu}$ isotopic ratio measurements).

\title{
STethads and WradeLs
}

Cross sections for this study are based on the ENDE/B. Version V.2 nuclear data files. Region-fependent multigroup cross sections in 9: broad energy groups trave been generatedi using the $M C^{2}-2 / S D X$ cell homogenization codes [4,5] for each of the EBR-II cell types.. The REBUS-3 reactor model of EBR-II is a three-dimensional (hexagonal-Z) full core model which explicitly models each frexagonal subassembly through Row 16 . An additional tow of hexagons (Row 17) is included in the REB.US-3 model representing the sodium pool. The reactor model inciudes three axial depletion regions in each of the core and blanket subassemblies. The neutronics solution uses DIF3D nodal diffusion theory [G. The control rods and safety rods are modeled explicitly with time-dependent positions. The REBUS-3 calculation for each EBR-II ran is a single burn step non-equilibrium caIculation in which all loading changes from the preceding reactor run have been modeled. The power is assumed to be constant over the bum step. The series of EBR-II runs inciufed in the present stady started with Rur I30A. (August. I984) and extended through 67 reantor sub-runs to Run $154 \mathrm{~F}$, that is, analysis of these runs required 67 separate REHUS-3 non-equilibrium caIculations. 
EBR-II has been utilized as an irradiation facility to test IFR metal fuels. Irradiated test subassemblies have included binary (U-10Zr) and temary (UI-xPu-10Zr) fuel elements of various designs. Because all three of the lead IFR test subassembires (X4I9, $X+20$, and $X 42 I)$ are mixed fuel types, direct comparison cannot be made between the REBUS-3 results and the analytical chemistry measurements of bumup and $\mathrm{U}$ and $\mathrm{Pu}$ isotopic fractions for these three subassemblies. That is, the compositions of the different element types in these subassemblies have been homogenized within the node (hexagon) in the REBUS-3 analysis. Furthermore, the depletion in REBUS-3 has been zone or block depletion, thereby lacking point values. And finally, the not uncommon procedure of reconstitution and funther irradiation of many test assemblies (including these three experimental assemblies) is well beyond the standard abilities of REBUS-3. The RCT code has been developed to reconstruct the intra-nodal distributions of power density, bumup. nuclide fensities, group fluxes, and fast and total fluences from nodal-diffusion/depletion caIcurations performed in hexagonal-Z geomenY using REBUS-3/DIFID.

\section{Discussion of Results}

The EBR-II experimental data available for comparison wittr EEBUS-3/RCT calculations include burnup measurements, $U$ and Pu isotopic fraction measurements, and gamma scan data. The current study focuses anly on chemistry measurements performed by personnel of the Argonne-West Analytical Laboratory on meral fuel This fimits the database, at this time, to measurements on four experimental assemblies, namely, the three Iead IFR test assembilies X4I9, $X 420$, and $X 42 I_{r}$ and the experimental assembily $X 425$. Assembly $X 425$ contains 6I new HT9 clad IFR metal fixel elements with as-built fissite Ioadings designed to closely match those of $\mathrm{X} 4 \mathrm{I} \mathrm{q}_{\mathrm{r}} \mathrm{X} 420$, and $\mathrm{X} 42 \mathrm{I}$.

The bumup measurements are based on Isotope Dilution Mass Spectroscopic (IDMS) analysis of fission products ${ }^{159} \mathrm{La}$ and ${ }^{148} \mathrm{NE}$. The overall accuracy of the Analytical Laboratory's determination of bumup on irradiated IFR fitel (U-IOZr or U-xPU-IOZr) up to 20 atom percent burmup is estimated to be $\pm 4 \%$ provided the diffusion of La and Nd is only in the radial (and not axial) direction. Funthermore, there is an absolute uncertainty of $4 \%$ in the measurement of the power level of EBR-II Because the power level is a direct nomalization to the bumup values: obtaine in the REBUS-3/RCT analysis, the $4 \%$ uncentainty in the reactor power contributes a $4 \%$ uncerrainty to the calculated values in addition to other nuclear data, methods, and modeling uncertainties. Therefore, agreement between calculated and experimental bumup values: within about 6\% should be considered good.

There are data for 14 samples - each measured with $\mathrm{La}$ and $\mathrm{Nd}$ bumup monitors. The agreement between the calculated and measured bumup values for the IFR metal furel is viry good. The mean value $\pm I \sigma$ spreadi of all $28 \mathrm{C} / \mathrm{E}$ values is $1.029 \pm 0.032$. The range of the $28 \mathrm{C} / \mathrm{E}$ values is from 0.960 to 1.087 , these extreme values being La bunup measurements of two samples of the same U-8Pu-IOZr temary pirn in X4I9 aL - I $9 \%$. The mean and I $\sigma$ spread in the C/E values according to fuel type are shown below.

$\begin{array}{lc}\text { Burnup C/E's } \\ \text { U-I0Zr } & \begin{array}{c}\text { Mean Value } \pm I \sigma \\ \text { U-8Pu-I0Zr }\end{array} \\ \text { U-I9Pu-I0Zr } & 1.024 \pm 0.012 \\ & 1.027 \pm 0.038 \\ & 1.036 \pm 0.033\end{array}$

The silgint differences in the mean C/E values according to fuel type are not significant. In fact, there are no significant trends in the $C / E$ biases. The set of $\operatorname{six} C / E$ values for the binary pin in $\mathrm{X}+19$ at $-1.8 \%$ bumup are the best and most consistent set (i.e., closest to unity and to each other). Eowever, the best C/E's for a single sample were for the U-I9Pu-LOZr temary pin in 
X4I9B at - I2\% bumup, which vas the highest bumup measured.

Bumup dara is avariable at different axial positions for only three elements of IFR metal fuel, namely, for elements TI67, TO13, and TII9 of test assembily X4I9. For these three elements, the C/E value is lower near the top of the fuel column than at the middie and bottom. It is: naniral to question (i) whether this distributional bias is real, and (ii) does it portend a misprediction in the axial flux or power profile. Because these $C / E$ values all agree within 16 , the first question cannot be answered unequivocably without additional data (i.e., more comparisons of measure bumup distributions). However, ane can still consider the second question. For the U-I9Pu-IOZr element TI67 of assembly X419, the gamma scan of ${ }^{95} \mathrm{Nb}$ has been measureci. These data have been compared with the REBUS-3/RCT calculated values of axial power density and bumup for element TI67. The calculated distributions are more convex or "buckled" than the measured dati, that is, the calculated values are Iower at botfr the top and bortom of the fuel columin. Eowever, it must again be noted that the differences are small $(<4 \%)$

II and Pu isotopic analyses have aIso been perfomed by the Analytical Laboratory on the same four IFR test assemblies. The determinations are again obtained from mass spectrometer measurements. The averall accuracy of performing isotopic measurements on irradiated IFR furel

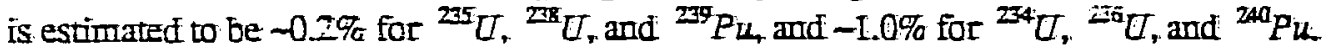

In the case of X419, X420, and X421, isotopic data have been measured from radial drilling of the irradiated samples. As might be expected, the radial variation within the samples was fetermined to be quite small. The experimental values used in this sudy represent average values: for the entire axial section of the samples. The comparisor of calculated and measured values of the $U$ and Pu isotopic fractions as a function of bumup for $\mathrm{U}-10 \mathrm{Zr}$, U-8PU-10Zr, and U-ISPU-IOZr IFR fuel have been made. The agreement between measured and caIculated values is quite good.

$\mathrm{U}$ and $\mathrm{Pu}$ isctopic fractions have also been measured for the two bumup samples of element T456 (U-8Fu-10Zr) in rest assembly X425A. Again, agreement is quitz good, except for ${ }^{24 I} P_{L \text {, }}$ which represents a very small component of the Pu in element $T 456$. One of the two C/E values: for the ${ }^{342} P_{u}$ weight fraction is -9\% higfi and the other -27\% Iow. The measurements in X419, $\bar{X} 420$, and $X 42 I$ did not report the ${ }^{2 A 2} \mathrm{Pu}$ weighit fractions.

\section{Carchusĩans}

The principle conciusions from the present sudy are:

I. REBUS- 2 analysis using nodal diffusion theory with a three-dimensional hexagonaI- $Z$ full core model and ENDF/B-V.I nuclear dara can adiequately follow EBR-II fureI management and depletion.

2 Detrils of nuclide density, bummp, power density, and fluence within the node or hexagonal subassembly can adequately be recoustructed using the RCT code.

3. Comparisons have been made of REBUS-3/RCT analyses with experimental values, including the analysis of mixed fuel type test assemblies that have had complex irradiation histories (such as multiple reconstitutions, multiple core insertions/removals, and multiple core tocations and subassembly orientation).

4. Results of these comparisons for burmup and $\mathrm{U}$ and $\mathrm{Pu}$ isotopic fractions are quite good (i.e. generally within experimental uncertainties) and indicate the REBUS-3/RCT methodolgies can meet botif operational and material control and accountancy requirements for the IFR. 


\section{REFERENCES}

1. Y. I Chang, "The Inregral Fast Reactor," Nucl Tech, 88, I29 (November I989).

2 B. I. Toppel, "A User's Guide to the REBUS-3 Fuel Cycle Analysis Capability" ANL-83-2, Argonne NationaI Laborarory, March 1983.

3. W. S. Yang, P. I. Finck, and H. Khalil, "Reconstruction of Pin Bumup Characteristics from Nodal Calcularions in Hexagonal Geometry," Proc. of Inti. Conf. on the Physics of Reactors: Operation, Design and Computation, Marseille, France, VoL 2, VIII-22, April 23-27, 1990.

4. H. Henryson H. B. I. ToppeI, and C. G. Stenberg, " $M C^{2}-2$ : A Code to Calculate Fast Neutron Spectra and Mulfigroup Cross Sections," ANL-8I44 (ENDF-239), Argonne Nitional Laboratory, (1976).

5. W. M Stacey, Ir et aI., Trans. Am. Nucl. Soc., 15, 292 (1972).

6. R. D. Lawrence, "The DIF3D Nodal Neutronics Option for Two- and Three-Dimensional Diffusion Theory Calculations in Hexagonal Geometry," ANL-83-I, Argonne National Laboratory, March 1983. 